\title{
REVIEW
}

\section{Unraveling oxyntomodulin, GLP1's enigmatic brother}

\author{
Alessandro Pocai \\ Diabetes and Endocrinology, Merck Research Laboratories, Merck Sharp and Dohme Corp., 126 East Lincoln Avenue, Rahway, New Jersey 07065, USA \\ (Correspondence should be addressed to A Pocai; Email: alessandro_pocai@merck.com)
}

\begin{abstract}
Oxyntomodulin (OXM) is a peptide secreted from the $\mathrm{L}$ cells of the gut following nutrient ingestion. OXM is a dual agonist of the glucagon-like peptide-1 receptor (GLP1R) and the glucagon receptor (GCGR) combining the effects of GLP1 and glucagon to act as a potentially more effective treatment for obesity than GLP1R agonists. Injections of OXM in humans cause a significant reduction in weight and appetite, as well as an increase in energy expenditure. Activation of GCGR is classically associated with an elevation in glucose
\end{abstract}

levels, which would be deleterious in patients with T2DM, but the antidiabetic properties of GLP1R agonism would be expected to counteract this effect. Indeed, OXM administration improved glucose tolerance in diet-induced obese mice. Thus, dual agonists of the GCGR and GLP1R represent a new therapeutic approach for diabetes and obesity with the potential for enhanced weight loss and improvement in glycemic control beyond those of GLP1R agonists.

Journal of Endocrinology (2012) 215, 335-346

\section{Introduction}

As the prevalence of type 2 diabetes increases, there is a medical need for additional antihyperglycemic agents that offer improved efficacy in glycemic control and tolerability. Obesity is an important risk factor for a number of debilitating chronic conditions such as T2DM, dyslipidemia, and hypertension (Bray 2004). However, several T2DM therapies have been associated with weight gain, most profoundly for the sulfonylureas, meglitinides, and thiazolidinediones (TZDs) as well as for insulin. Recent work on understanding the physiological function of proglucagon-derived peptides has renewed interest in glucagon-based therapeutics. One of these peptides is glucagon-like peptide-1 (GLP1), which is secreted from the L cells of the gastrointestinal tract and lowers blood glucose levels primarily by promoting insulin secretion and by inhibiting glucagon secretion (Holst 2000). GLP1 has been found to decrease food intake and inhibit gastric emptying (Holst 2000, D'Alessio 2008). GLP1 is rapidly inactivated by dipeptidyl peptidase-4 (DPP4) and its renal clearance is relatively fast (Field et al. 2009). Accordingly, new drugs based on GLP1 receptor (GLP1R) agonism and DPP4 inhibition have been approved for the treatment of type 2 diabetes, but the magnitude of weight loss at tolerated doses is modest (Amori et al. 2007). Nevertheless, protease-resistant GLP1R agonists (Drucker et al. 2010, Htike et al. 2012, Nauck 2012) represent a new class of antihyperglycemic agents that reduce body weight (D'Alessio 2008, Vilsboll et al. 2012) and are currently being tested for the treatment of obesity (Astrup et al. 2012).

\section{The preproglucagon family: historical overview and} tissue-specific posttranslational processing

Oxyntomodulin (OXM) is a 37-amino acid peptide secreted in proportion to nutrient ingestion (Ghatei et al. 1983, Le Quellec et al. 1992, Holst 1997, Drucker 2005) comprising the entire 29-amino acid sequence of glucagon, with an 8-amino acid carboxy-terminal extension that results from the processing of the preproglucagon precursor (Fig. 1; Campos et al. 1994, Larsen et al. 1997). The processing of proglucagon is tissue specific, producing from a single protein different hormones depending on the tissue considered. In pancreatic $\alpha$ cells, prohormone convertase 2 (PC2) generates predominantly glucagon (Rouille et al. 1994, Kieffer \& Habener 1999, Furuta et al. 2001), whereas in intestinal L cells present in the jejunum, ileum, and colon, PC 1/3 predominantly produces glicentin, OXM, GLP1, and GLP2 (Ghatei et al. 1983, Le Quellec et al. 1992, Holst 1997, Drucker 2005, Brubaker 2012, Habib et al. 2012). Similar processing is also thought to occur in the same neurons in the nucleus of the solitary tract (NTS) in the hindbrain (Holst 2007; Fig. 1). 


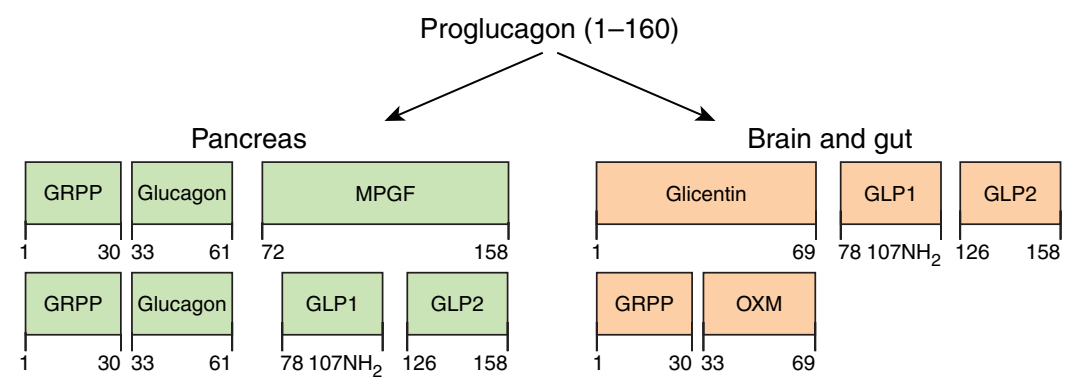

Figure 1 Tissue-specific processing of proglucagon. Differential posttranslational processing of proglucagon in the pancreas and in the gut and brain. Preproglucagon is proteolytically cleaved in a tissue-specific manner by prohormone convertases 1 and 2 . The numbers in the figure indicate amino acid positions in the 160-amino acid proglucagon sequence. In the pancreas, processing yields the glucagon sequence, whereas the region containing the GLP1 and GLP2 peptides is secreted as a single inactive fusion called major proglucagon fragment (MPGF) or GLP1 and GLP2. Posttranslational processing in the gut and brain results in the secretion of GLP1 and GLP2, while the glucagon sequence remains in a larger peptide, glicentin or glicentin-related pancreatic peptide (GRPP), and oxyntomodulin.

Sutherland \& De Duve (1948) described for the first time glucagon-like substances in extracts of intestinal mucosa as identified using a bioassay (Holst 1983). The description of a glucagon RIA by Unger et al. (1959), (1961) and (1962) made it possible to confirm that the intestinal extracts contained peptides cross-reacting in the RIA (gut 'glucagon-like immunoreactivity', GLI). The first evidence of the existence of OXM was generated in 1968 when it was discovered that the gut GLI consisted of at least two peptides. Two distinct moieties with GLI were secreted in response to an oral glucose load (Unger et al. 1968, Valverde et al. 1968). One with a C-terminal octapeptide extension (SP-1, spacer peptide-1, or KA-8 or IP-1, intervening peptide) was named OXM (Bataille et al. 1981b, Dubrasquet et al. 1982) for its ability to modulate gastric acid secretion in gastric oxyntic glands (Bataille et al. 1981a,b,c, 1982), and the other with the same C-terminal extension plus an N-terminal extension of 30 amino acids, was named glicentin (Sundby et al. 1976, Thim \& Moody 1981, Holst 1982). Larsson et al. (1975) using immunohistochemistry and radioimmunoanalysis showed in 1975 that disseminated cells that predominate in the ileum and colon intestinal mucosa store gut-type glucagon, reporting for the first time the spatial tissue distribution of OXM in the gut. The distribution of glucagon-related peptides in the human gastrointestinal mucosa was later described by Baldissera \& Holst (1984).

\section{Receptors and post-receptor pathways activated by OXM}

OXM binds to and is a full $\sim$ equipotent agonist of the human GLP1R and glucagon receptor (GCGR)-mediated cAMP accumulation, although with reduced affinity compared with the cognate agonists GLP1 and glucagon
(Bataille et al. 1982, Baldissera et al. 1988, Gros et al. 1993, Schepp et al. 1996, Baggio et al. 2004, Jorgensen et al. 2007, Pocai et al. 2009, Kosinski et al. 2012). Despite being a full agonist at the human GLP1R, OXM was found to be a full agonist in recruiting $\beta$-arrestin 2 to the GCGR, but partial agonists in recruiting $\beta$-arrestin ( $\beta$-arrestin 1 and $\beta$-arrestin 2) and G-protein-coupled receptor (GPCR) kinase 2 to the GLP1R. Consistent with the properties of a partial agonist, OXM was a functional antagonist of GLP1-induced agonist response in $\beta$-arrestin 2 recruitment. It has been suggested that OXM is a GLP1R-biased agonist relative to GLP1 having less preference toward cAMP signaling relative to phosphorylation of ERK1/2, but similar preference for cAMP relative to $\mathrm{Ca}^{2+}$ (Jorgensen et al. 2007). These findings imply that the GLP1R-mediated in vivo effects of OXM could differ from that of GLP1 (Koole et al. 2010). Currently, no data are available on whether OXM interact with other family B GPCRs such as GLP2 and glucose-dependent insulinotropic peptide (GIP) receptors. Peripheral administration of OXM results in increased c-Fos in the arcuate nucleus (ARC), but not in the brainstem region (Dakin et al. 2004), and using manganese-enhanced magnetic resonance to follow the pattern of neuronal activation, OXM and GLP1 result in activation of different hypothalamic pathways (Chaudhri et al. 2006, Parkinson et al. 2009). While these differences may be simply due to a different brain penetration, it is plausible that the engagement of additional receptor(s) and/or the above reported difference on GLP1R signaling pathways may explain the differences.

\section{OXM and body weight}

OXM causes weight loss in obese patients (Wynne et al. 2005) and rodents (Dakin et al. 2001, Baggio et al. 2004) via 
suppression of food intake and increases in energy expenditure (Baggio et al. 2004, Wynne et al. 2006). OXM is a dual agonist at the GLP1R and GCGR in vitro (Baldissera et al. 1988, Gros et al. 1993, Pocai et al. 2009). The anorectic effects of central administrations of GLP1 and OXM are abolished by co-administration of the GLP1R antagonist, exendin(9-39), and are not observed in Glp $1 r^{-/-}$mice, suggesting that the central effect of OXM is mediated by the GLP1R (Turton et al. 1996, Dakin et al. 2001, Baggio et al. 2004, Sowden et al. 2007, Wynne et al. 2010). While data obtained with the truncated lizard peptide exendin(9-39) needs to be carefully evaluated as it was shown to function either as a GLP1 and GLP2 receptor antagonist and to displace GIP binding in vitro (Wheeler et al. 1995, Brubaker et al. 1997, Tang-Christensen et al. 2000), the lack of OXM efficacy seen in Glp $1 r^{-/-}$mice demonstrated that the initial anorectic effect of OXM is mediated solely by activation of the GLP1R (Baggio et al. 2004, Sowden et al. 2007). However, other acute effects of OXM, including stimulation of heart rate and energy expenditure, appear to be independent of GLP1R, suggesting that OXM has both GLP1R-dependent and independent effects in vivo (Baggio et al. 2004, Sowden et al. 2007).

These data led several investigators to hypothesize that the differential effect of OXM vs GLP1 could be mediated by activation of the GCGR or an as of yet unidentified OXMspecific receptor. Recently, several publications (Du et al. 2012, Kosinski et al. 2012) expanded the initial findings on the mechanism of action of OXM and demonstrated that OXM has glycogenolytic properties in perfused mice liver showing that OXM can functionally activate the GCGR (Kosinski et al. 2012). Du et al. (2012) using a GLP1R agonist peptide with a mutation of Gln (Q) $\rightarrow$ Glu (E) (OXMQ3E) in position 3 that dials out activity on GCGR (Santoprete et al. 2011; Fig. 2), demonstrated that OXM, but not OXMQ3E, stimulated liver ketogenesis in wild-type mice. A similar effect was observed in Glp1r $r^{-/-}$but not in $\mathrm{Gcgr}^{-/-}$mice demonstrating that this effect of OXM is mediated by GCGR activation (Du et al. 2012). When equimolar doses of OXM (GLP1R/GCGR dual agonist) and OXMQ3E (selective GLP1 agonist) were infused in obese mice, OXM exerted superior weight loss and lipid lowering with comparable glucose lowering to OXMQ3E (Kosinski et al. 2012). Moreover, chronic infusion of OXM in $\mathrm{Glp}_{1} r^{-/-}$mice retained some of the body weight effect observed in lean
GLP1 HAEGTFTSDVS SYLEGQAAK E F IAWLVKGR
$1 . .$. 11
21. 31

Glucagon HSQGTFYSDYS KYLDSRRAQ DFVQWLMNT

Glicentin RSLQDTEEKSRSFSASAADPLSDPDQMNEDKR HSQGTFTSDYS KYLDSRRAQ DFVQWLMNTKRNRNNIA

OXM HSQGTFTSDYS KYLDSRRAQ DFVQWLMNT KRNRNNIA

OXMQ3E HSEEGTFTSDYS KYLDSRRAQ DFVQWLMNT KRNRNNIA

Figure 2 Sequence comparisons of GLP1(7-36) amide, glucagon(1-29), glicentin, OXM, and OXMQ3E. wild-type mice, and pharmacological blockade of the GCGR during OXM infusion demonstrated that the additional body weight lowering observed with OXM vs OXMQ3E is mediated by activation of the GCGR. This study showed the involvement of the GCGR together with GLP1R activation to the body weight lowering effect of OXM, but it did not completely dismiss the potential contribution of an OXM-specific receptor as minor weight loss was observed in the group treated with a small molecule GCGR antagonist alone (Kosinski et al. 2012). The superior weight loss efficacy of OXM vs GLP1R agonism is consistent with previous research on glucagon and energy homeostasis in humans and rodents. Repeated administration of glucagon was first shown to inhibit food intake in man over 50 years ago (Schulman et al. 1957), and aside from its well-known hyperglycemic action, glucagon increases thermogenesis, satiety, lipolysis, fatty acid oxidation, and ketogenesis (Salter 1960, Salter et al. 1960, Penick \& Hinkle 1961, Langhans et al. 1982, Habegger et al. 2010, Jones et al. 2012). A critical physiological role of glucagon in the maintenance of whole-body energy homeostasis was supported by a recent study in T2D patients where a dosedependent increase in body weight was observed following pharmacological blockade of the GCGR (Engel et al. 2011).

\section{OXM and glucose metabolism}

Studies have suggested that OXM may play a role in glucose homeostasis. Chronic treatment with OXM results in superior weight-lowering and comparable antihyperglycemic effect to a GLP1R-selective agonist (Kosinski et al. 2012). This is likely achieved through body weight reduction due to the causal link between obesity and type 2 diabetes (Karra \& Batteram 2010) as well as direct enhancement of glucosedependent insulin secretion (Maida et al. 2008, Parlevliet et al. 2008, Du et al. 2012). Activation of GCGR is associated with an elevation in glucose levels but the simultaneous agonism at the GLP1R would be expected to counteract this effect. Acute treatment with OXM improves glucose tolerance during a glucose challenge in mice (Maida et al. 2008, Parlevliet et al. 2008). Moreover, OXM administration improved glucose intolerance by enhancing glucose disposal during a hyperinsulinemic clamp study performed in dietinduced insulin-resistant mice (Parlevliet et al. 2008). It has been proposed that following a single injection, OXM acts solely via GLP1R to modulate glucose homeostasis (Maida et al. 2008). However, OXM was reported to increase hepatic glucose production during a euglycemic-hyperinsulinemic clamp performed in diet-induced obese mice, suggesting activation of the hepatic GCGR in vivo (Parlevliet et al. 2008). Recently, it was demonstrated that while acute treatment with OXM improves glucose metabolism during a glucose tolerance test and during a hyperglycemic clamp in mice, a matched pair peptide without GCGR activity (OXMQ3E) (Fig. 2) exerted better glucose-lowering properties compared with OXM administration (Du et al. 2012). The same authors 
showed decreased glucose tolerance in OXM-infused compared with vehicle-infused Glp $1 r^{-/-}$mice. The lack of effect observed following a single i.p. injection of OXM during a glucose tolerance test in Glp $1 r^{-/-}$mice (Maida et al. 2008) may be explained by the fact that Glp1r ${ }^{-1-}$ mice are glucose intolerant and resistant to diet-induced obesity; hence, the acute glucoregulatory effect of a single injection of OXM could be confounded by compensatory mechanisms associated with chronic deletion of the GLP1R (Flamez et al. 1999). To further strengthen these data, hyperglycemic clamps performed in $\mathrm{Gcgr}^{-/-}$mice showed a similar effect of OXM and OXMQ3E infusion on glucose metabolism in the absence of a functional GCGR. This study demonstrated that simultaneous activation of the GLP1R counteracts the hyperglycemic effect of glucagon in vivo. The glucoselowering effect of OXM is mostly mediated by GLP1R activation and activation of the GCGR appears to limit the acute antihyperglycemic efficacy of OXM while contributing to the insulinotropic properties of OXM (Du et al. 2012). Glucagon has been reported to increase glucose levels following i.c.v. administration in rats (Marubashi et al. 1985, Amir 1986). However, Mighiu et al. (2012) recently demonstrated that intrahypothalamic glucagon suppresses hepatic glucose production and counteracts the direct hepatic stimulatory effect of circulating glucagon on liver glucose production in rodents during a pancreatic clamp. Therefore, activation of the GCGR in discrete CNS areas may contribute to the improvement of whole-body glucose metabolism in animals treated with OXM.

\section{Other actions of OXM}

Gastrointestinal effects

OXM decreases gastric acid and pancreatic exocrine secretion (Bataille et al. 1981a, Dubrasquet et al. 1982, Ghatei et al. 1983, Biedzinski et al. 1987, Schjoldager et al. 1989, Le Quellec et al. 1992, Anini et al. 2000) and increases intestinal glucose uptake in preclinical species (Collie et al. 1997). Acute administration of OXM does not decrease gastric emptying in mice (Maida et al. 2008) while i.v. infusion of OXM inhibits gastric emptying in humans (Schjoldager et al. 1989). GLP1 is thought to reduce postprandial glucose excursion primarily via deceleration of gastric emptying in rodents and humans (Wettergren et al. 1993, Willms et al. 1996), although this effect seems to desensitize after multiple administrations (Meier et al. 2005, Nauck et al. 2011) and glucagon has also been reported to decrease gastric emptying (Habegger et al. 2010). Further studies are required to confirm or reconcile these divergent findings on gastric emptying in mice and humans potentially involved in the effect of OXM on the regulation of glucose and energy metabolism (Fig. 3).

\section{Pancreatic effects}

OXM has been reported to decrease pancreatic secretion through the nervous system in rats (Anini et al. 2000) and stimulate the endocrine pancreas to secrete insulin, somatostatin, and glucagon (Baldissera et al. 1988, Schjoldager et al. 1988,

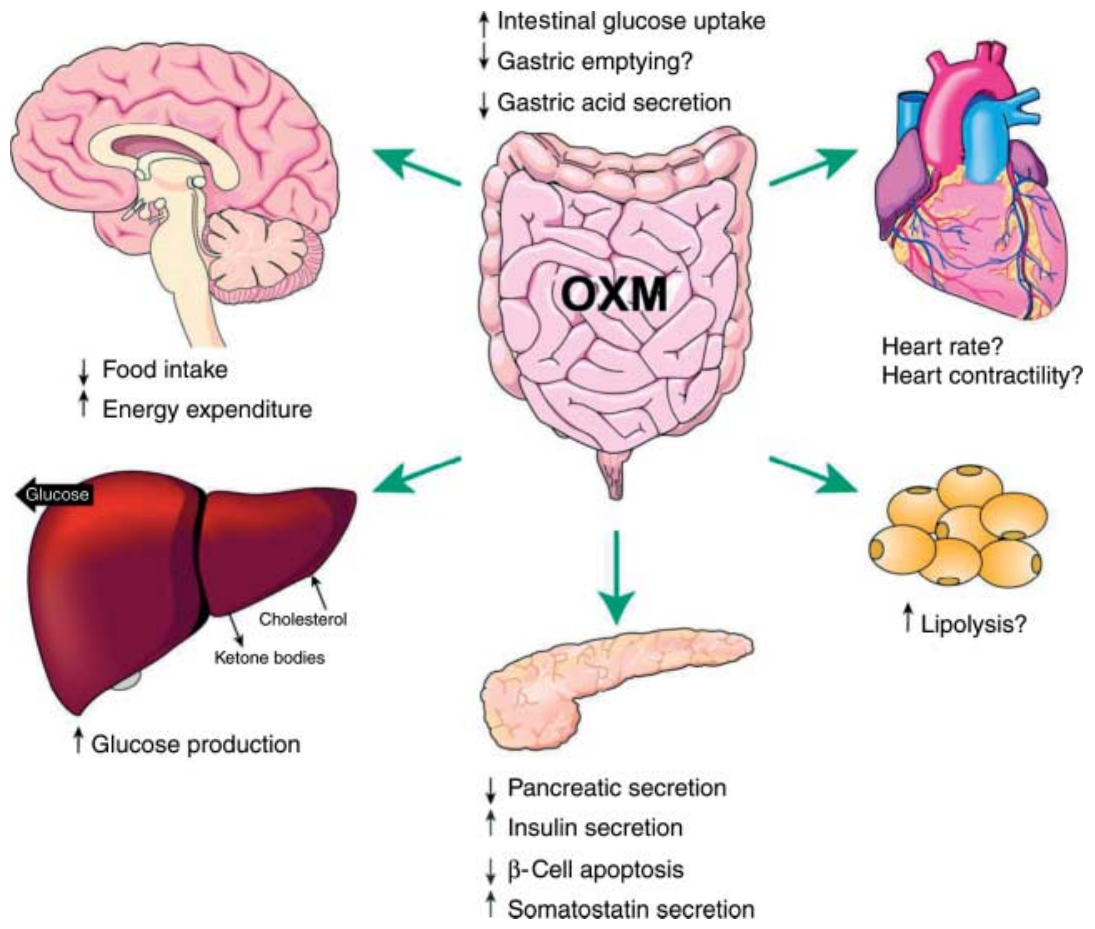

Figure 3 Reported effects of oxyntomodulin. 
Maida et al. 2008, Parlevliet et al. 2008, Du et al. 2012). OXM is capable of stimulating insulin secretion in a glucose-dependent manner. This effect is likely mediated through sensory nerves expressing the GLP1R and direct activation of the $\beta$-cells GLP1R and GCGR (Drucker et al. 1987, Ahren 2004, Vahl et al. 2007, Maida et al. 2008, Du et al. 2012). It is not known whether the GCGR is involved in OXM-mediated insulin secretion via sensory pathways. Furthermore, OXM reduces $\beta$-cell apoptosis and increases pancreatic insulin content in diabetic mice treated with streptozotocin, an effect mediated at least in part via a direct GLP1R-dependent mechanism (Maida et al. 2008). Recently, the GLP1R-mediated proliferative effect on the $\beta$-cell has been demonstrated to require a signaling complex GLP1R/ $\beta$-arrestin $1 / \mathrm{c}-\mathrm{Src}$ in INS832/13 cells (Talbot et al. 2012; Fig. 3).

\section{Cardiovascular effects}

Glucagon and GLP1 have positive inotropic and chronotropic actions on the heart (Farah \& Tuttle 1960, Buse et al. 1973, Gonzalez-Munoz et al. 2008, Grieve et al. 2009). OXM administration increased heart rate in wild-type mice (Sowden et al. 2007). Involvement of the GCGR in the effects of OXM on mouse heart is consistent with the increased heart rate observed in $G l p 1 r^{-1-}$ mice (Sowden et al. 2007). Further studies are required to investigate the effect of OXM on the heart, as no increase in heart rate was detected following administration of OXM in rat and humans (Wynne et al. 2005, 2006, Sowden et al. 2007). The GLP1R/ GCGR dual agonist ZP2495 has been shown to increase glucose oxidation and glycolytic rates in insulin-resistant hearts of obese insulin-resistant rats but, unlike glucagon, it did not compromise the energetic state of the hearts and GLP1 agonism had no effect on cardiac metabolism (Axelsen et al. 2012). The authors suggested that GLP1R/GCGR dual agonists may have inotropic and energy-preserving effects in insulin-resistant hearts and that these effects could be beneficial for the treatment of heart failure or cardiogenic shock in subjects with insulin resistance (Axelsen et al. 2012).

\section{Renal effects}

GLP1 agonists and DPP4 inhibitors cause moderate blood pressure lowering and lipid lowering in humans that may contribute to the reported cardiovascular benefits of this class of antidiabetic drugs (Mega et al. 2011, Liu et al. 2012, Panchapakesan et al. 2013). Glucagon causes natriuresis with changes in kidney sodium handling. Enhanced proximal tubular sodium reabsorption and a higher prevalence of hypertension have been associated with the Gly40Ser polymorphism of the GCGR gene resulting in a mutated receptor less responsive to glucagon (Strazzullo et al. 2001, Barbato et al. 2003). Consistently, a trend toward blood pressure increase was observed during pharmacological GCGR antagonism in T2D patients in a 4-week Phase IIa proof-of-concept study (Ruddy et al. 2011). No data so far have been published on the renal effects of OXM.

\section{Neuroprotective effects}

In preclinical studies, GLP1 agonists and DPP4 inhibitors (in association with GLP1 elevation) have been shown to counteract memory impairment, protect neurons from oxidative stress, and reduce plaque formation and the chronic inflammation response in the brains of mouse models of Alzheimer's disease, Parkinson's disease, and other degenerative diseases (Wu et al. 2003, D'Amico et al. 2010, Holscher 2012). GLP1R agonists are currently explored for the treatment of neurodegeneration (Mega et al. 2011, Liu et al. 2012, Panchapakesan et al. 2013), and glucagon has been recently reported to preserve neurological function following brain trauma in diabetic rats (Abu Fanne et al. 2011). No published reports so far have explored the effect of OXM or GLP1R/GCGR dual agonists on neuroprotection. The above studies suggest that simultaneous activation of the GLP1R and GCGR could result in potential beneficial effects in neurodegenerative disorders.

\section{OXM, physiological or pharmacological role?}

Because of the structural similarities of the proglucagon products, investigating the endogenous levels of OXM is difficult as 'OXM-like immunoreactivity' (OLI) has been estimated mostly using a two-step subtraction RIA or a RIA using an OXM C-terminal specific antibody (Blache et al. 1988). In the subtraction RIA, one assay is used to measure the concentration of total glucagon, using antibodies to the nonterminal epitopes of glucagon, which cross-react with glucagon, glicentin, and OXM (Fig. 2). A second assay is used to measure glucagon using antibodies to the exposed C-terminal of glucagon. To estimate OLI, the level of pancreatic glucagon is subtracted from the level of total glucagon (Kervran et al. 1987).

Using the OXM C-terminal octapeptide-specific antibody (Blache et al. 1988, Le Quellec et al. 1992), it was shown that, following i.d. administration of a meal, OLI raised in anesthetized rat plasma from $20 \cdot 1 \pm 2 \cdot 7$ to $176 \cdot 1 \pm 12 \cdot 2 \mathrm{pmol} / 1$ at $30 \mathrm{~min}$ (Anini et al. 1999). Using the same RIA, Le Quellec et al. (1998) determined that fasting and meal-stimulated levels in healthy children were $71 \pm 10$ and $130 \pm 26 \mathrm{pmol} / 1$ respectively and that the physiological 24-h OLI profile in human plasma shows a diurnal variation independent of food intake; the lowest levels were found in the early morning $(\sim 13.5 \mathrm{pmol} / \mathrm{l})$ and the highest levels were found in the evening $(\sim 30 \cdot 8 \mathrm{pmol} / \mathrm{l})$ (Le Quellec et al. 1992). More recently, the subtraction RIA (Ghatei et al. 1983) has been used to estimate the OLI concentration in humans treated with OXM (Wynne et al. 2005). S.c. OXM (400 nmol preprandially) administered three times daily in overweight and obese subjects over a 4-week period resulted in 
a significant weight loss of $2 \cdot 3 \mathrm{~kg}$ (Wynne et al. 2005). The endogenous fasting level of OLI was found to be $97 \cdot 4 \pm 5 \cdot 5 \mathrm{pmol} / 1$, increasing to $116 \cdot 5 \pm 10 \cdot 4 \mathrm{pmol} / 1$ after a meal. OLI increased tenfold ( $972 \pm 165 \mathrm{pmol} / \mathrm{l}) 30 \mathrm{~min}$ after self-administration of OXM. These levels are similar to those found in gastrointestinal disease such as the levels reported in patients with tropical malabsorption (tropical sprue, approximately tenfold elevation vs normal patients) (Besterman et al. 1979), patients who have had small intestinal resection (Besterman et al. 1982), and following jejuneal ileal bypass surgery (Holst et al. 1979, Sarson et al. 1981). The same authors using a similar experimental design and OXM administration demonstrated that 4-day s.c. self-administration of preprandial OXM $(400 \mathrm{nmol})$ three times daily increased energy expenditure and decreased energy intake in overweight and obese volunteers (Wynne et al. 2006). The baseline plasma OXM levels were $41 \pm 7 \mathrm{pmol} / 1$ increasing to $63 \pm 16 \mathrm{pmol} / 1$ postprandially. When participants self-administered OXM, levels increased to $658 \pm 85 \mathrm{pmol} / 1$ immediately before the study meal (Wynne et al. 2006). Holst's group using a different subtraction RIA to obtain OLI concentrations (Holst et al. 1976) reported fasting and postprandial plasma levels of 20-30 pmol/1 (Falken et al. 2011).

The issues with the accurate quantification of OXM remain a confounder as a proportion of the OLI is represented by glicentin and different assays result in different readouts. Recently, Halquist et al. (2012) reported a two-dimensional reversed phase ion pair chromatography-tandem mass spectrometry approach for the analysis of OXM in rat plasma. This LC-MS method may provide new avenues of data that may not have been seen with other method platforms.

Based on the data available, it is unclear what the absolute values of OXM/OLI are in plasma during fasting and following a meal. It is, therefore, difficult to make conclusions about a potential physiological role of OXM. OXM shows similar functional potencies $\left(\mathrm{EC}_{50}, \mathrm{cAMP}\right.$ production) at the GLP1R and GCGR (Baldissera et al. 1988, Gros et al. 1993, Holst 2000, Pocai et al. 2009, Kosinski et al. 2012) at $\sim 1-2$ orders of magnitude higher than the plasma levels of OXM/OLI reported in postprandial state and then only approach $\mathrm{EC}_{50}$ plasma levels when OXM is exogenously administered (Wynne et al. 2005, 2006). Based only on peripheral plasma OXM levels, it is unlikely that the endogenous levels of OXM result in physiological effects. More sophisticated technologies measuring the levels of OXM in critical sites such as the vagus or discrete brainspecific areas involved in the regulation of energy homeostasis are not readily available and are required to make any further conclusion. In these sites, the levels of OXM are anticipated to be higher in the postprandial state. Similarly, animal (Vahl et al. 2007) and human (Plamboeck et al. 2012) studies have demonstrated that an intact vagal innervation is important for the effect of GLP1 in the maintenance of glucose homeostasis. GLP1 is a substrate of DPP4 and is rapidly metabolized to GLP1 (9-37) or GLP1(9-36)NH2. DPP4, among other tissues and cell types, is found on the surface of endothelial cells of capillaries in the intestinal mucosa adjacent to the sites of GLP1 secretion (Hansen et al. 1999, Baggio \& Drucker 2007). Consequently, $<25 \%$ of newly secreted GLP1 enters the portal vein in intact form and only $\sim 10-15 \%$ reaches the systemic circulation in the intact insulinotropic form where DPP4 also exists as a soluble form (Pridal et al. 1996, Mentlein 1999). OXM has a short half-life in circulation of $\sim 12 \mathrm{~min}$ in humans (Schjoldager et al. 1988) and $\sim 6 \mathrm{~min}$ in the rat (Kervran et al. 1990). It is removed by renal clearance and is a substrate of DPP4 (Zhu et al. 2003). Evidence of the involvement of DPP4 in the breakdown of OXM in vivo came from a study in which co-administration of OXM and a DPP4 inhibitor resulted in a greater reduction of food intake (Druce \& Bloom 2006). The midsection of OXM may also be a target for degradative enzymes such as the ectopeptidases (Hupe-Sodmann et al. 1997) and neutral endopeptidase 24.11 (NEP-24.11, neprilysin) (Hupe-Sodmann et al. 1995, Deacon 2005, Plamboeck et al. 2005). This observation raised concerns regarding the relevance of portal GLP1 or other peptide concentrations in regulating glucose homeostasis and other pharmacodynamic effects and represents a potential limitation in the majority of studies that rely only on measurement of systemic levels of native peptides (Vahl et al. 2007).

Therefore, it is possible that the circulating active levels of OXM reflect, as in the case of GLP1, just a small portion of the secreted product and that the concentration at the site of secretion in the gut or brain is sufficient to elicit physiological responses (Kervran et al. 1990). It is also possible that additional receptors are involved in the action of OXM or that OXM acts synergistically when secreted together with other peptides (Field et al. 2010) recapitulating the postRoux-en-Y gastric bypass situation (Ashrafian et al. 2011, Jorgensen et al. 2012). The understanding of the role of OXM as a potential physiological regulator of appetite and energy expenditure would be strengthened by the identification of a specific OXM receptor, by studies employing specific OXM antagonists or immuno-neutralizing antibodies that block the effects of OXM, but not glucagon or GLP1, or with genetic mouse models.

\section{Therapeutic potential}

The only treatments to date that produce lasting weight reduction are gastric banding and gastric bypass surgery, although the associated risk and costs limit their use. Patients that undergo gastric bypass have alterations of several signals that may contribute to their reduced appetite and enhanced glucose homeostasis. Among the changes consistently observed following RYGB are an exaggerated postprandial increase in OXM, glucagon, PYY, and GLP1 (Chandarana \& Batterham 2012). Administration of endogenous gut peptides or more metabolically stable analog represents a potential long-term therapeutic approach to obesity and diabetes. OXM administered three times a day preprandially was demonstrated to reduce body weight in humans 
(Wynne et al. 2005) and preclinical data suggest that OXM may have glucose-lowering properties (Maida et al. 2008, Parlevliet et al. 2008). However, the clinical utility of OXM is limited, mainly because of its short circulating half-life (Schjoldager et al. 1988). Repeated daily doses of large amounts of peptide would be required to elicit its effect, entailing a treatment regimen inconvenient for patients and not economically viable. Because glucagon and GLP1 share $\sim 50 \%$ amino acid sequence identity (Fig. 2), several groups have recently developed protease-resistant GLP1R/GCGR dual agonist peptides that are resistant to peptidase degradation (Day et al. 2009, Kerr et al. 2010, Liu et al. 2010, Santoprete et al. 2011). Two independent papers reported the use of GLP1R/GCGR co-agonists as being of enhanced efficacy relative to pure GLP1R agonists in the treatment of rodent obesity, with simultaneous improvement in glycemic control (Day et al. 2009, Pocai et al. 2009). Two DPP4-resistant OXM analogs have been tested in obese mice to compare the effects of dual agonism relative to activation of the GLP1R (Pocai et al. 2009). One analog, being a dual agonist at the GLP1R and GCGR (DualAG), is the OXM peptide with a cholesterol group attached to the C-terminal end. The alternative analog is a GLP1R-selective analog (GLPAG) with an equal affinity for the GLP1R but no significant activity at the GCGR due to a mutation from glutamine to glutamate that abolished the interaction with the GCGR (Santoprete et al. 2011). Obese mice administered with DualAG had superior weight loss and lipid lowering compared with the GLP1R-selective agonist (Pocai et al. 2009). Another dual GLP1R and GCGR agonist strategy involved screening a series of chimeric DPP4-resistant PEGylated peptides. The chimeric peptide was optimized to decrease food intake, reduce body weight, and increase GLP1 activity to neutralize the hyperglycemic effects of glucagon with weekly s.c. injections to diet-induced obese mice (Day et al. 2009). The enhanced weight loss observed with GLP1R/GCGR dual agonists (Day et al. 2009, Pocai et al. 2009, Kosinski et al. 2012) has triggered important questions about the ideal ratio of receptor activation. Specifically, what is the appropriate amount of GLP1R activation that buffer the hyperglycemic risk posed by GCGR activation. When a long-acting dual agonist was given to Glp $1 r^{-1-}$ mice, the decrease in body weight was no longer associated with improvement in glucose metabolism (Day et al. 2009), highlighting the importance of an appropriate GLP1R engagement in preventing GCGR-mediated increase in glucose production. A recent report using a spectrum of receptor selectivity demonstrated that a dual agonist peptide with comparable functional potencies at the GLP1R and GCGR maximizes the weight loss and minimizes the hyperglycemic risk associated with GCGR activation in mice (Day et al. 2012). Another OXM analog, OXM6421, when injected in lean mice was observed to have a longer half-life than endogenous OXM and resulted in reduced intake of food as well as enhanced expenditure of energy (Liu et al. 2010). ZP2929, a chimeric peptide capable of fully activating both GLP1R and GCGR, improved glycemic control without body weight gain in $\mathrm{db} / \mathrm{db}$ mice when combined with long-acting insulin (Fosgerau et al. 2011). Recently, Zealand Pharma announced the starting of a Phase I development of ZP2929 for the treatment of T2DM and/or obesity (Diabetes.co.uk, Sep 14, 2012) and Transition Therapeutics confirmed in a press release the completion of a Phase 1 study with TT-401, a weekly GLP1R/GCGR dual agonist developed for the treatment of diabetes (www. transitiontherapeutics.com/media/news.php, June 6, 2012).

\section{Conclusion}

Several trials have clearly demonstrated that lifestyle interventions (UKPDS 1995) and T2DM therapies such as sulfonylureas, metformin, and TZD result in progressive deterioration of glycemic control in T2DM patients associated with $\beta$-cell decline (Kahn et al. 2006). Therefore, restoration of insulin secretion and $\beta$-cell mass and function is a critical goal of future diabetes treatments. Thus far, incretin-based therapies (GLP1R agonists and DPP4 inhibitors) are providing durable glycemic control with improved insulin resistance and $\beta$-cell function (Klonoff et al. 2008, Derosa \& Maffioli 2012, Derosa et al. 2012a, b, van Genugten et al. 2012).

With these initial promising results from incretin mimetics and incretin enhancers, the next generation of diabetes drugs will likely focus on the alternate delivery for injectables (Owens 2002, Lee et al. 2009, Sloop et al. 2010) and the combined activation of more than one receptor. Simultaneous activation of GLP1R and GCGR with chimeric peptides and in the future nonpeptide orally available GLP1R/GCGR dual agonists is a conceivable option to achieve improved therapeutic goals. It will be critical to deepen our understanding of the mechanism of action and how structurally related peptides like GLP1 and glucagon interact with their respective receptors. Understanding of receptor oligomerization, heteromerization, and binding cooperativity will allow an improved understanding of how ligands should be designed to maximize the simultaneous activation of these complexes (Roed et al. 2012, Schelshorn et al. 2012, Whitaker et al. 2012). Finally, characterization of the post-receptor signaling of these closely related GPCR in the glucagon family will allow a better understanding of the pathways that need to be selectively modulated to achieve the desired effect while avoiding others responsible for undesirable adverse effects.

\section{Declaration of interest}

The author is employee of Merck Sharp and Dohme Corp.

\section{Funding}

This research did not receive any specific grant from any funding agency in the public, commercial or not-for-profit sector.

Journal of Endocrinology (2012) 215, 335-346 


\section{References}

Abu Fanne R, Banai S, Chorin U, Rogowski O, Keren G \& Roth A 2011 Diagnostic yield of extensive infectious panel testing in acute pericarditis. Cardiology 119 134-139. (doi:10.1159/000330928)

Ahren B 2004 Sensory nerves contribute to insulin secretion by glucagon-like peptide-1 in mice. American Journal of Physiology. Regulatory, Integrative and Comparative Physiology 286 R269-R272. (doi:10.1152/ajpregu. 00423.2003)

Amir S 1986 Central glucagon-induced hyperglycemia is mediated by combined activation of the adrenal medulla and sympathetic nerve endings. Physiology and Behavior 37 563-566. (doi:10.1016/0031-9384(86)90286-6)

Amori RE, Lau J \& Pittas AG 2007 Efficacy and safety of incretin therapy in type 2 diabetes: systematic review and meta-analysis. Journal of the American Medical Association 298 194-206. (doi:10.1001/jama.298.2.194)

Anini Y, Fu-Cheng X, Cuber JC, Kervran A, Chariot J \& Roz C 1999 Comparison of the postprandial release of peptide YY and proglucagonderived peptides in the rat. Pflügers Archiv 438 299-306. (doi:10.1007/ s004240050913)

Anini Y, Jarrousse C, Chariot J, Nagain C, Yanaihara N, Sasaki K, Bernad N, Le Nguyen D, Bataille D \& Roze C 2000 Oxyntomodulin inhibits pancreatic secretion through the nervous system in rats. Pancreas 20 348-360. (doi:10.1097/00006676-200005000-00003)

Ashrafian H, Athanasiou T, Li JV, Bueter M, Ahmed K, Nagpal K, Holmes E, Darzi A \& Bloom SR 2011 Diabetes resolution and hyperinsulinaemia after metabolic Roux-en-Y gastric bypass. Obesity Reviews 12 e257-e272. (doi:10.1111/j.1467-789X.2010.00802.x)

Astrup A, Carraro R, Finer N, Harper A, Kunesova M, Lean ME, Niskanen L, Rasmussen MF, Rissanen A, Rossner S et al. 2012 Safety, tolerability and sustained weight loss over 2 years with the once-daily human GLP-1 analog, liraglutide. International Journal of Obesity 36 843-854. (doi:10.1038/ ijo.2011.158)

Axelsen LN, Keung W, Pedersen HD, Meier E, Riber D, Kjolbye AL, Petersen JS, Proctor SD, Holstein-Rathlou NH \& Lopaschuk GD 2012 Glucagon and a glucagon-GLP-1 dual-agonist increases cardiac performance with different metabolic effects in insulin-resistant hearts. British Journal of Pharmacology 165 2736-2748. (doi:10.1111/j.1476-5381.2011.01714.x)

Baggio LL \& Drucker DJ 2007 Biology of incretins: GLP-1 and GIP. Gastroenterology 132 2131-2157. (doi:10.1053/j.gastro.2007.03.054)

Baggio LL, Huang Q, Brown TJ \& Drucker DJ 2004 Oxyntomodulin and glucagon-like peptide-1 differentially regulate murine food intake and energy expenditure. Gastroenterology 127 546-558. (doi:10.1053/j.gastro. 2004.04.063)

Baldissera FG \& Holst JJ 1984 Glucagon-related peptides in the human gastrointestinal mucosa. Diabetologia 26 223-228. (doi:10.1007/ BF00252412)

Baldissera FG, Holst JJ, Knuhtsen S, Hilsted L \& Nielsen OV 1988 Oxyntomodulin (glicentin-(33-69)): pharmacokinetics, binding to liver cell membranes, effects on isolated perfused pig pancreas, and secretion from isolated perfused lower small intestine of pigs. Regulatory Peptides $\mathbf{2 1}$ 151-166. (doi:10.1016/0167-0115(88)90099-7)

Barbato A, Russo P, Venezia A, Strazzullo V, Siani A \& Cappuccio FP 2003 Analysis of Gly40Ser polymorphism of the glucagon receptor (GCGR) gene in different ethnic groups. Journal of Human Hypertension 17 577-579. (doi:10.1038/sj.jhh.1001591)

Bataille D, Gespach C, Coudray AM \& Rosselin G 1981a 'Enteroglucagon': a specific effect on gastric glands isolated from the rat fundus. Evidence for an 'oxyntomodulin' action. Bioscience Reports 1 151-155. (doi:10.1007/ BF01117012)

Bataille D, Gespach C, Tatemoto K, Marie JC, Coudray AM, Rosselin G \& Mutt V 1981b Bioactive enteroglucagon (oxyntomodulin): present knowledge on its chemical structure and its biological activities. Peptides 2 (Suppl 2) 41-44. (doi:10.1016/0196-9781(81)90008-5)

Bataille D, Tatemoto K, Coudray AM, Rosselin G \& Mutt V 1981c Bioactive 'enteroglucagon' (oxyntomodulin): evidence for a C-terminal extension of the glucagon molecule. Comptes Rendus des Séances de l'Académie des Sciences. Série III, Sciences de la Vie 293 323-328.
Bataille D, Tatemoto K, Gespach C, Jornvall H, Rosselin G \& Mutt V 1982 Isolation of glucagon-37 (bioactive enteroglucagon/oxyntomodulin) from porcine jejuno-ileum. Characterization of the peptide. FEBS Letters 146 79-86. (doi:10.1016/0014-5793(82)80709-6)

Besterman HS, Cook GC, Sarson DL, Christofides ND, Bryant MG, Gregor M \& Bloom SR 1979 Gut hormones in tropical malabsorption. BMJ 2 1252-1255. (doi:10.1136/bmj.2.6200.1252)

Besterman HS, Adrian TE, Mallinson CN, Christofides ND, Sarson DL, Pera A, Lombardo L, Modigliani R \& Bloom SR 1982 Gut hormone release after intestinal resection. Gut 23 854-861. (doi:10.1136/gut.23. 10.854)

Biedzinski TM, Bataille D, Devaux MA \& Sarles H 1987 The effect of oxyntomodulin (glucagon-37) and glucagon on exocrine pancreatic secretion in the conscious rat. Peptides 8 967-972. (doi:10.1016/01969781(87)90122-7)

Blache P, Kervran A, Martinez J \& Bataille D 1988 Development of an oxyntomodulin/glicentin C-terminal radioimmunoassay using a 'thiolmaleoyl' coupling method for preparing the immunogen. Analytical Biochemistry 173 151-159. (doi:10.1016/0003-2697(88)90172-8)

Bray GA 2004 Medical consequences of obesity. Journal of Clinical Endocrinology and Metabolism 89 2583-2589. (doi:10.1210/jc.2004-0535)

Brubaker PL 2012 A beautiful cell (or two or three?) Endocrinology 153 2945-2948. (doi:10.1210/en.2012-1549)

Brubaker PL, Crivici A, Izzo A, Ehrlich P, Tsai CH \& Drucker DJ 1997 Circulating and tissue forms of the intestinal growth factor, glucagon-like peptide-2. Endocrinology 138 4837-4843. (doi:10.1210/en.138.11.4837)

Buse MG, Biggers JF, Drier C \& Buse JF 1973 The effect of epinephrine, glucagon, and the nutritional state on the oxidation of branched chain amino acids and pyruvate by isolated hearts and diaphragms of the rat. Journal of Biological Chemistry 248 697-706.

Campos RV, Lee YC \& Drucker DJ 1994 Divergent tissue-specific and developmental expression of receptors for glucagon and glucagon-like peptide-1 in the mouse. Endocrinology 134 2156-2164. (doi:10.1210/ en.134.5.2156)

Chandarana K \& Batterham RL 2012 Shedding pounds after going under the knife: metabolic insights from cutting the gut. Nature Medicine 18 668-669. (doi:10.1038/nm.2748)

Chaudhri OB, Parkinson JR, Kuo YT, Druce MR, Herlihy AH, Bell JD, Dhillo WS, Stanley SA, Ghatei MA \& Bloom SR 2006 Differential hypothalamic neuronal activation following peripheral injection of GLP-1 and oxyntomodulin in mice detected by manganese-enhanced magnetic resonance imaging. Biochemical and Biophysical Research Communications 350 298-306. (doi:10.1016/j.bbrc.2006.09.033)

Collie NL, Zhu Z, Jordan S \& Reeve JR Jr 1997 Oxyntomodulin stimulates intestinal glucose uptake in rats. Gastroenterology 112 1961-1970. (doi:10.1053/gast.1997.v112.pm9178688)

Dakin CL, Gunn I, Small CJ, Edwards CM, Hay DL, Smith DM, Ghatei MA \& Bloom SR 2001 Oxyntomodulin inhibits food intake in the rat. Endocrinology 142 4244-4250. (doi:10.1210/en.142.10.4244)

Dakin CL, Small CJ, Batterham RL, Neary NM, Cohen MA, Patterson M, Ghatei MA \& Bloom SR 2004 Peripheral oxyntomodulin reduces food intake and body weight gain in rats. Endocrinology 145 2687-2695. (doi:10.1210/en.2003-1338)

D'Alessio D 2008 Intestinal hormones and regulation of satiety: the case for CCK, GLP-1, PYY, and Apo A-IV. JPEN. Journal of Parenteral and Enteral Nutrition 32 567-568. (doi:10.1177/0148607108322401)

D'Amico M, Di Filippo C, Marfella R, Abbatecola AM, Ferraraccio F, Rossi F \& Paolisso G 2010 Long-term inhibition of dipeptidyl peptidase-4 in Alzheimer's prone mice. Experimental Gerontology 45 202-207. (doi:10.1016/j.exger.2009.12.004)

Day JW, Ottaway N, Patterson JT, Gelfanov V, Smiley D, Gidda J, Findeisen H, Bruemmer D, Drucker DJ, Chaudhary N et al. 2009 A new glucagon and GLP-1 co-agonist eliminates obesity in rodents. Nature Chemical Biology $\mathbf{5}$ 749-757. (doi:10.1038/nchembio.209)

Day JW, Smiley D, Carrington PE, Eiermann G, Chicchi G, Erion MD, Gidda J, Thornberry NA, Tschöp MH, Marsh DJ et al. 2012 Optimization 
of co-agonism at GLP-1 and glucagon receptors to safely maximize weight reduction in DIO-rodents. Peptide Science 98 443-450. (doi:10.1002/bip. 22072)

Deacon CF 2005 What do we know about the secretion and degradation of incretin hormones? Regulatory Peptides 128 117-124. (doi:10.1016/ j.regpep.2004.06.007)

Derosa G \& Maffioli P 2012 Dipeptidyl peptidase-4 inhibitors: 3 years of experience. Diabetes Technology and Therapeutics 14 350-364. (doi:10.1089/ dia.2011.0204)

Derosa G, Carbone A, Franzetti I, Querci F, Fogari E, Bianchi L, Bonaventura A, Romano D, Cicero AF \& Maffioli P 2012a Effects of a combination of sitagliptin plus metformin vs metformin monotherapy on glycemic control, $\beta$-cell function and insulin resistance in type 2 diabetic patients. Diabetes Research and Clinical Practice 98 51-60. (doi:10.1016/j. diabres.2012.05.022)

Derosa G, Ragonesi PD, Carbone A, Fogari E, Bianchi L, Bonaventura A, Romano D, Cicero AF \& Maffioli P $2012 b$ Vildagliptin added to metformin on $\beta$-cell function after a euglycemic hyperinsulinemic and hyperglycemic clamp in type 2 diabetes patients. Diabetes Technology and Therapeutics 14 475-484. (doi:10.1089/dia.2011.0278)

Druce MR \& Bloom SR 2006 Oxyntomodulin: a novel potential treatment for obesity. Treatments in Endocrinology 5 265-272. (doi:10.2165/00024677200605050-00001)

Drucker DJ 2005 Biologic actions and therapeutic potential of the proglucagon-derived peptides. Nature Clinical Practice. Endocrinology and Metabolism 1 22-31. (doi:10.1038/ncpendmet0017)

Drucker DJ, Philippe J, Mojsov S, Chick WL \& Habener JF 1987 Glucagonlike peptide I stimulates insulin gene expression and increases cyclic AMP levels in a rat islet cell line. PNAS 84 3434-3438. (doi:10.1073/ pnas.84.10.3434)

Drucker DJ, Dritselis A \& Kirkpatrick P 2010 Liraglutide. Nature Reviews. Drug Discovery 9 267-268. (doi:10.1038/nrd3148)

Du X, Kosinski JR, Lao J, Shen X, Petrov A, Chicchi GG, Eiermann GJ \& Pocai A 2012 Differential effects of oxyntomodulin and GLP-1 on glucose metabolism. American Journal of Physiology. Endocrinology and Metabolism 303 E265-E271. (doi:10.1152/ajpendo.00142.2012)

Dubrasquet M, Bataille D \& Gespach C 1982 Oxyntomodulin (glucagon-37 or bioactive enteroglucagon): a potent inhibitor of pentagastrin-stimulated acid secretion in rats. Bioscience Reports 2 391-395. (doi:10.1007/ BF01119301)

Engel SS, Xu L, Andryuk PJ, Davies MJ, Amatruda J, Kaufman K \& Goldstein BJ 2011 Efficacy and tolerability of MK-0893, a glucagon receptor antagonist (GRA), in patients with type 2 diabetes (T2DM). Diabetes 60 (Suppl 1) A85. (doi:10.2337/db11-1-378)

Falken Y, Hellstrom PM, Holst JJ \& Naslund E 2011 Changes in glucose homeostasis after Roux-en-Y gastric bypass surgery for obesity at day three, two months, and one year after surgery: role of gut peptides. Journal of Clinical Endocrinology and Metabolism 96 2227-2235. (doi:10.1210/ jc.2010-2876)

Farah A \& Tuttle R 1960 Studies on the pharmacology of glucagon. Journal of Pharmacology and Experimental Therapeutics 129 49-55.

Field BC, Chaudhri OB \& Bloom SR 2009 Obesity treatment: novel peripheral targets. British Journal of Clinical Pharmacology 68 830-843. (doi:10.1111/j.1365-2125.2009.03522.x)

Field BC, Wren AM, Peters V, Baynes KC, Martin NM, Patterson M, Alsaraf S, Amber V, Wynne K, Ghatei MA et al. 2010 PYY3-36 and oxyntomodulin can be additive in their effect on food intake in overweight and obese humans. Diabetes 59 1635-1639. (doi:10.2337/ db09-1859)

Flamez D, Gilon P, Moens K, Van Breusegem A, Delmeire D, Scrocchi LA, Henquin JC, Drucker DJ \& Schuit F 1999 Altered cAMP and Ca ${ }^{2+}$ signaling in mouse pancreatic islets with glucagon-like peptide- 1 receptor null phenotype. Diabetes 48 1979-1986. (doi:10.2337/diabetes.48.10.1979)

Fosgerau KS, Larsen M, BaeK SA, Meier E, Groendahl C \& Bak HH 2011 Combination of long-acting insulin with the dual GluGLP-1 agonist ZP2929 causes improved glycemic control without body weight gain in db/db mice. Diabetes 60 (Suppl 1) A418. (doi:10.2337/db11-1487-1624)
Furuta M, Zhou A, Webb G, Carroll R, Ravazzola M, Orci L \& Steiner DF 2001 Severe defect in proglucagon processing in islet A-cells of prohormone convertase 2 null mice. Journal of Biological Chemistry 276 27197-27202. (doi:10.1074/jbc.M103362200)

van Genugten RE, van Raalte DH \& Diamant M 2012 Dipeptidyl peptidase4 inhibitors and preservation of pancreatic islet-cell function: a critical appraisal of the evidence. Diabetes, Obesity and Metabolism 14 101-111. (doi:10.1111/j.1463-1326.2011.01473.x)

Ghatei MA, Uttenthal LO, Christofides ND, Bryant MG \& Bloom SR 1983 Molecular forms of human enteroglucagon in tissue and plasma: plasma responses to nutrient stimuli in health and in disorders of the upper gastrointestinal tract. Journal of Clinical Endocrinology and Metabolism $\mathbf{5 7}$ 488-495. (doi:10.1210/jcem-57-3-488)

Gonzalez-Munoz C, Nieto-Ceron S, Cabezas-Herrera J \& Hernandez-Cascales J 2008 Glucagon increases contractility in ventricle but not in atrium of the rat heart. European Journal of Pharmacology $\mathbf{5 8 7}$ 243-247. (doi:10.1016/j.ejphar.2008.04.001)

Grieve DJ, Cassidy RS \& Green BD 2009 Emerging cardiovascular action of the incretin hormone glucagon-like peptide-1: potential therapeutic benefits beyond glycaemic control? British Journal of Pharmacology 157 1340-1351. (doi:10.1111/j.1476-5381.2009.00376.x)

Gros L, Thorens B, Bataille D \& Kervran A 1993 Glucagon-like peptide1-(7-36) amide, oxyntomodulin, and glucagon interact with a common receptor in a somatostatin-secreting cell line. Endocrinology 133 631-638. (doi:10.1210/en.133.2.631)

Habegger KM, Heppner KM, Geary N, Bartness TJ, DiMarchi R \& Tschop MH 2010 The metabolic actions of glucagon revisited. Nature Reviews. Endocrinology 6 689-697. (doi:10.1038/nrendo.2010.187)

Habib AM, Richards P, Cairns LS, Rogers GJ, Bannon CA, Parker HE, Morley TC, Yeo GS, Reimann F \& Gribble FM 2012 Overlap of endocrine hormone expression in the mouse intestine revealed by transcriptional profiling and flow cytometry. Endocrinology 153 3054-3065. (doi:10.1210/ en.2011-2170)

Halquist MS, Sakagami M \& Karnes HT 2012 Determination of oxyntomodulin, an anorectic polypeptide, in rat plasma using 2D-LCMS/MS coupled with ion pair chromatography. Journal of Chromatography. B, Analytical Technologies in the Biomedical and Life Sciences 903 102-111. (doi:10.1016/j.jchromb.2012.06.047)

Hansen L, Deacon CF, Orskov C \& Holst JJ 1999 Glucagon-like peptide-1(7-36)amide is transformed to glucagon-like peptide-1-(9-36)amide by dipeptidyl peptidase IV in the capillaries supplying the $\mathrm{L}$ cells of the porcine intestine. Endocrinology 140 5356-5363. (doi:10.1210/en.140.11.5356)

Holscher C 2012 Potential role of glucagon-like peptide-1 (GLP-1) in neuroprotection. CNS Drugs 26 871-882. (doi:10.2165/11635890000000000-00000)

Holst JJ 1982 Evidence that enteroglucagon (II) is identical with the C-terminal sequence (residues 33-69) of glicentin. Biochemical Journal 207 381-388.

Holst JJ 1983 Gut glucagon, enteroglucagon, gut glucagon-like immunoreactivity, glicentin - current status. Gastroenterology 84 1602-1613.

Holst JJ 1997 Enteroglucagon. Annual Review of Physiology 59 257-271. (doi:10.1146/annurev.physiol.59.1.257)

Holst JJ 2000 Gut hormones as pharmaceuticals. From enteroglucagon to GLP-1 and GLP-2. Regulatory Peptides 93 45-51. (doi:10.1016/S01670115(00)00185-3)

Holst JJ 2007 The physiology of glucagon-like peptide 1. Physiological Reviews 87 1409-1439. (doi:10.1152/physrev.00034.2006)

Holst JJ, Christiansen J \& Kuhl C 1976 The enteroglucagon response to intrajejunal infusion of glucose, triglycerides, and sodium chloride, and its relation to jejunal inhibition of gastric acid secretion in man. Scandinavian Journal of Gastroenterology 11 297-304.

Holst JJ, Sorensen TI, Andersen AN, Stadil F, Andersen B, Lauritsen KB \& Klein HC 1979 Plasma enteroglucagon after jejunoileal bypass with 3:1 or 1:3 jejunoileal ratio. Scandinavian Journal of Gastroenterology 14 205-207. (doi:10.3109/00365527909179871)

Htike ZZ, Khunti K \& Davies M 2012 A review of exenatide: optimizing glycemic control and associated cardiovascular risk factors in type 2 diabetes. Diabetes Therapy 3 1-16. (doi:10.1007/s13300-012-0003-x) 
Hupe-Sodmann K, McGregor GP, Bridenbaugh R, Goke R, Goke B, Thole H, Zimmermann B \& Voigt K 1995 Characterisation of the processing by human neutral endopeptidase 24.11 of GLP-1(7-36) amide and comparison of the substrate specificity of the enzyme for other glucagon-like peptides. Regulatory Peptides 58 149-156. (doi:10.1016/ 0167-0115(95)00063-H)

Hupe-Sodmann K, Goke R, Goke B, Thole HH, Zimmermann B, Voigt K \& McGregor GP 1997 Endoproteolysis of glucagon-like peptide (GLP)-1 (7-36) amide by ectopeptidases in RINm5F cells. Peptides 18 625-632. (doi:10.1016/S0196-9781(97)00123-X)

Jones BJ, Tan T \& Bloom SR 2012 Minireview: glucagon in stress and energy homeostasis. Endocrinology 153 1049-1054. (doi:10.1210/en.2011-1979)

Jorgensen R, Kubale V, Vrecl M, Schwartz TW \& Elling CE 2007 Oxyntomodulin differentially affects glucagon-like peptide-1 receptor $\beta$-arrestin recruitment and signaling through $\mathrm{G} \alpha(\mathrm{s})$. Journal of Pharmacology and Experimental Therapeutics 322 148-154. (doi:10.1124/jpet.107.120006)

Jorgensen NB, Jacobsen SH, Dirksen C, Bojsen-Moller KN, Naver L, Hvolris L, Clausen TR, Wulff BS, Worm D, Lindqvist Hansen D et al. 2012 Acute and long-term effects of Roux-en-Y gastric bypass on glucose metabolism in subjects with type 2 diabetes and normal glucose tolerance. American Journal of Physiology. Endocrinology and Metabolism 303 E122-E131. (doi:10.1152/ajpendo.00073.2012)

Kahn SE, Haffner SM, Heise MA, Herman WH, Holman RR, Jones NP, Kravitz BG, Lachin JM, O’Neill MC, Zinman B et al. 2006 Glycemic durability of rosiglitazone, metformin, or glyburide monotherapy. New England Journal of Medicine 355 2427-2443. (doi:10.1056/NEJMoa066224)

Karra E \& Batteram RL 2010 The role of gut hormones in the regulation of body weight and energy homeostasis. Molecular and Cellular Endocrinology 316 120-128. (doi:10.1016/j.mce.2009.06.010)

Kerr BD, Flatt PR \& Gault VA 2010 (D-Ser2)Oxm(mPEG-PAL): a novel chemically modified analogue of oxyntomodulin with antihyperglycaemic, insulinotropic and anorexigenic actions. Biochemical Pharmacology 80 1727-1735. (doi:10.1016/j.bcp.2010.08.010)

Kervran A, Blache P \& Bataille D 1987 Distribution of oxyntomodulin and glucagon in the gastrointestinal tract and the plasma of the rat. Endocrinology 121 704-713. (doi:10.1210/endo-121-2-704)

Kervran A, Dubrasquet M, Blache P, Martinez J \& Bataille D 1990 Metabolic clearance rates of oxyntomodulin and glucagon in the rat: contribution of the kidney. Regulatory Peptides 31 41-52. (doi:10.1016/01670115(90)90194-2)

Kieffer TJ \& Habener JF 1999 The glucagon-like peptides. Endocrine Reviews 20 876-913. (doi:10.1210/er.20.6.876)

Klonoff DC, Buse JB, Nielsen LL, Guan X, Bowlus CL, Holcombe JH, Wintle ME \& Maggs DG 2008 Exenatide effects on diabetes, obesity, cardiovascular risk factors and hepatic biomarkers in patients with type 2 diabetes treated for at least 3 years. Current Medical Research and Opinion 24 275-286. (doi:10.1185/030079908X253870)

Koole C, Wootten D, Simms J, Valant C, Sridhar R, Woodman OL, Miller LJ, Summers RJ, Christopoulos A \& Sexton PM 2010 Allosteric ligands of the glucagon-like peptide 1 receptor (GLP-1R) differentially modulate endogenous and exogenous peptide responses in a pathway-selective manner: implications for drug screening. Molecular Pharmacology $\mathbf{7 8}$ 456-465. (doi:10.1124/mol.110.065664)

Kosinski JR, Hubert J, Carrington PE, Chicchi GG, Mu J, Miller C, Cao J, Bianchi E, Pessi A, Sinharoy R et al. 2012 The glucagon receptor is involved in mediating the body weight lowering effects of oxyntomodulin. Obesity 20 1566-1571. (doi:10.1038/oby.2012.67)

Langhans W, Zeiger U, Scharrer E \& Geary N 1982 Stimulation of feeding in rats by intraperitoneal injection of antibodies to glucagon. Science $\mathbf{2 1 8}$ 894-896. (doi:10.1126/science.7134979)

Larsen PJ, Tang-Christensen M, Holst JJ \& Orskov C 1997 Distribution of glucagon-like peptide- 1 and other preproglucagon-derived peptides in the rat hypothalamus and brainstem. Neuroscience 77 257-270. (doi:10.1016/ S0306-4522(96)00434-4)

Larsson LI, Holst JJ, Hakanson R \& Sundler F 1975 Distribution and properties of glucagon immunoreactivity in the digestive tract of various mammals: an immunohistochemical and immunochemical study. Histochemistry 44 281-290. (doi:10.1007/BF00490364)
Lee KC, Chae SY, Kim TH, Lee S, Lee ES \& Youn YS 2009 Intrapulmonary potential of polyethylene glycol-modified glucagon-like peptide-1s as a type 2 anti-diabetic agent. Regulatory Peptides 152 101-107. (doi:10.1016/ j.regpep.2008.09.008)

Le Quellec A, Kervran A, Blache P, Ciurana AJ \& Bataille D 1992 Oxyntomodulin-like immunoreactivity: diurnal profile of a new potential enterogastrone. Journal of Clinical Endocrinology and Metabolism 74 1405-1409. (doi:10.1210/jc.74.6.1405)

Le Quellec A, Clapie M, Callamand P, Lehmann M, Kervran A, Bataille D \& Rieu D 1998 Circulating oxyntomodulin-like immunoreactivity in healthy children and children with celiac disease. Journal of Pediatric Gastroenterology and Nutrition 27 513-518. (doi:10.1097/00005176-199811000-00003)

Liu YL, Ford HE, Druce MR, Minnion JS, Field BC, Shillito JC, Baxter J, Murphy KG, Ghatei MA \& Bloom SR 2010 Subcutaneous oxyntomodulin analogue administration reduces body weight in lean and obese rodents. International Journal of Obesity 34 1715-1725. (doi:10.1038/ijo.2010.110)

Liu WJ, Xie SH, Liu YN, Kim W, Jin HY, Park SK, Shao YM \& Park TS 2012 Dipeptidyl peptidase IV inhibitor attenuates kidney injury in streptozotocin-induced diabetic rats. Journal of Pharmacology and Experimental Therapeutics 340 248-255. (doi:10.1124/jpet.111.186866)

Maida A, Lovshin JA, Baggio LL \& Drucker DJ 2008 The glucagon-like peptide-1 receptor agonist oxyntomodulin enhances $\beta$-cell function but does not inhibit gastric emptying in mice. Endocrinology 149 5670-5678. (doi:10.1210/en.2008-0336)

Marubashi S, Tominaga M, Katagiri T, Yamatani K, Yawata Y, Hara M \& Sasaki H 1985 Hyperglycaemic effect of glucagon administered intracerebroventricularly in the rat. Acta Endocrinologica 108 6-10. (doi:10.2337/ db12-1-377)

Mega C, de Lemos ET, Vala H, Fernandes R, Oliveira J, Mascarenhas-Melo F, Teixeira F \& Reis F 2011 Diabetic nephropathy amelioration by a low-dose sitagliptin in an animal model of type 2 diabetes (Zucker diabetic fatty rat). Experimental Diabetes Research 2011 162092. (doi:10.1155/2011/162092)

Meier JJ, Kemmeries G, Holst JJ \& Nauck MA 2005 Erythromycin antagonizes the deceleration of gastric emptying by glucagon-like peptide 1 and unmasks its insulinotropic effect in healthy subjects. Diabetes $\mathbf{5 4}$ 2212-2218. (doi:10.2337/diabetes.54.7.2212)

Mentlein R 1999 Dipeptidyl-peptidase IV (CD26) - role in the inactivation of regulatory peptides. Regulatory Peptides 85 9-24. (doi:10.1016/S01670115(99)00089-0)

Mighiu PI, Yue JT, Filippi BM \& Lam TK 2012 Hypothalamic glucagon signaling regulates glucose production. Diabetes 61 (Suppl 1) A55.

Nauck MA 2012 The design of the liraglutide clinical trial programme. Diabetes, Obesity and Metabolism 14 (Suppl 2) 4-12. (doi:10.1111/j.14631326.2012.01573.x)

Nauck MA, Kemmeries G, Holst JJ \& Meier JJ 2011 Rapid tachyphylaxis of the glucagon-like peptide 1-induced deceleration of gastric emptying in humans. Diabetes 60 1561-1565. (doi:10.2337/db10-0474)

Owens DR 2002 New horizons - alternative routes for insulin therapy. Nature Reviews. Drug Discovery 1 529-540. (doi:10.1038/nrd836)

Panchapakesan U, Mather A \& Pollock C 2013 Role of GLP-1 and DPP-4 in diabetic nephropathy and cardiovascular disease. Clinical Science 124 17-26. (doi:10.1042/CS20120167)

Parkinson JR, Chaudhri OB, Kuo YT, Field BC, Herlihy AH, Dhillo WS, Ghatei MA, Bloom SR \& Bell JD 2009 Differential patterns of neuronal activation in the brainstem and hypothalamus following peripheral injection of GLP-1, oxyntomodulin and lithium chloride in mice detected by manganese-enhanced magnetic resonance imaging (MEMRI). Neurolmage 44 1022-1031. (doi:10.1016/j.neuroimage.2008.09.047)

Parlevliet ET, Heijboer AC, Schroder-van der Elst JP, Havekes LM, Romijn JA, Pijl H \& Corssmit EP 2008 Oxyntomodulin ameliorates glucose intolerance in mice fed a high-fat diet. American Journal of Physiology. Endocrinology and Metabolism 294 E142-E147. (doi:10.1152/ ajpendo.00576.2007)

Penick SB \& Hinkle LE Jr 1961 Depression of food intake induced in healthy subjects by glucagon. New England Journal of Medicine 264 893-897. (doi:10.1056/NEJM196105042641801) 
Plamboeck A, Holst JJ, Carr RD \& Deacon CF 2005 Neutral endopeptidase 24.11 and dipeptidyl peptidase IV are both mediators of the degradation of glucagon-like peptide 1 in the anaesthetised pig. Diabetologia 48 1882-1890. (doi:10.1007/s00125-005-1847-7)

Plamboeck S, Deacon C, Wetter-Gren A, Svendsen L, Meisner S, Hovendahl C, Holst JJ, Knop F \& Vilsboll T 2012 Reduced incretin effect in truncal vagotomized subjects. Diabetes 61 (Suppl 1) A95. (doi:10.2337/ $\mathrm{db} 12-1-377)$

Pocai A, Carrington PE, Adams JR, Wright M, Eiermann G, Zhu L, Du X, Petrov A, Lassman ME, Jiang G et al. 2009 Glucagon-like peptide $1 /$ glucagon receptor dual agonism reverses obesity in mice. Diabetes $\mathbf{5 8}$ 2258-2266. (doi:10.2337/db09-0278)

Pridal L, Deacon CF, Kirk O, Christensen JV, Carr RD \& Holst JJ 1996 Glucagon-like peptide-1(7-37) has a larger volume of distribution than glucagon-like peptide-1(7-36)amide in dogs and is degraded more quickly in vitro by dog plasma. European Journal of Drug Metabolism and Pharmacokinetics 21 51-59. (doi:10.1007/BF03190278)

Roed SN, Orgaard A, Jorgensen R \& De Meyts P 2012 Receptor oligomerization in family B1 of G-protein-coupled receptors: focus on BRET investigations and the link between GPCR oligomerization and binding cooperativity. Frontiers in Endocrinology 3 62. (doi:10.3389/fendo. 2012.00062)

Rouille Y, Westermark G, Martin SK \& Steiner DF 1994 Proglucagon is processed to glucagon by prohormone convertase PC2 in $\alpha$ TC1- 6 cells. PNAS 91 3242-3246. (doi:10.1073/pnas.91.8.3242)

Ruddy M, Luncenford J, Li S, Cilissen C, Stoch A, Wagner J, Amatruda J, Herman G \& Kaufman K 2011 Inhibition of glucagon-induced hyperglycemia predicts glucose lowering efficacyantagonist, MK-0893, in type 2 diabetes (T2DM). Diabetes 60 (Suppl 1) A85. (doi:10.2337/ db11-1-378)

Salter JM 1960 Metabolic effects of glucagon in the Wistar rat. American Journal of Clinical Nutrition 8 535-539.

Salter JM, Ezrin C, Laidlaw JC \& Gornall AG 1960 Metabolic effects of glucagon in human subjects. Metabolism 9 753-768.

Santoprete A, Capito E, Carrington PE, Pocai A, Finotto M, Langella A, Ingallinella P, Zytko K, Bufali S, Cianetti S et al. 2011 DPP-IV-resistant, long-acting oxyntomodulin derivatives. Journal of Peptide Science 17 270-280. (doi:10.1002/psc.1328)

Sarson DL, Scopinaro N \& Bloom SR 1981 Gut hormone changes after jejunoileal (JIB) or biliopancreatic (BPB) bypass surgery for morbid obesity. International Journal of Obesity 5 471-480.

Schelshorn D, Joly F, Mutel S, Hampe C, Breton B, Mutel V \& Lutjens R 2012 Lateral allosterism in the glucagon receptor family: glucagon-like peptide 1 induces G-protein-coupled receptor heteromer formation. Molecular Pharmacology 81 309-318. (doi:10.1124/mol.111.074757)

Schepp W, Dehne K, Riedel T, Schmidtler J, Schaffer K \& Classen M 1996 Oxyntomodulin: a cAMP-dependent stimulus of rat parietal cell function via the receptor for glucagon-like peptide-1 (7-36)NH2. Digestion 57 398-405. (doi:10.1159/000201367)

Schjoldager BT, Baldissera FG, Mortensen PE, Holst JJ \& Christiansen J 1988 Oxyntomodulin: a potential hormone from the distal gut. Pharmacokinetics and effects on gastric acid and insulin secretion in man. European Journal of Clinical Investigation 18 499-503. (doi:10.1111/j.1365-2362.1988. tb01046.x)

Schjoldager B, Mortensen PE, Myhre J, Christiansen J \& Holst JJ 1989 Oxyntomodulin from distal gut. Role in regulation of gastric and pancreatic functions. Digestive Diseases and Sciences 34 1411-1419. (doi:10.1007/ BF01538078)

Schulman JL, Carleton JL, Whitney G \& Whitehorn JC 1957 Effect of glucagon on food intake and body weight in man. Journal of Applied Physiology 11 419-421.

Sloop KW, Willard FS, Brenner MB, Ficorilli J, Valasek K, Showalter AD, Farb TB, Cao JX, Cox AL, Michael MD et al. 2010 Novel small molecule glucagon-like peptide-1 receptor agonist stimulates insulin secretion in rodents and from human islets. Diabetes 59 3099-3107. (doi:10.2337/ db10-0689)

Sowden GL, Drucker DJ, Weinshenker D \& Swoap SJ 2007 Oxyntomodulin increases intrinsic heart rate in mice independent of the glucagon-like peptide-1 receptor. American Journal of Physiology. Regulatory, Integrative and Comparative Physiology 292 R962-R970. (doi:10.1152/ajpregu.00405. 2006)

Strazzullo P, Iacone R, Siani A, Barba G, Russo O, Russo P, Barbato A, D’Elia L, Farinaro E \& Cappuccio FP 2001 Altered renal sodium handling and hypertension in men carrying the glucagon receptor gene (Gly40Ser) variant. Journal of Molecular Medicine 79 574-580. (doi:10.1007/ s001090100257)

Sundby F, Jacobsen H \& Moody AJ 1976 Purification and characterization of a protein from porcine gut with glucagon-like immunoreactivity. Hormone and Metabolic Research 8 366-371. (doi:10.1055/s-0028-1093615)

Sutherland EW \& De Duve C 1948 Origin and distribution of the hyperglycemic-glycogenolytic factor of the pancreas. Journal of Biological Chemistry 175 663-674.

Talbot J, Joly E, Prentki M \& Buteau J $2012 \beta$-Arrestin1-mediated recruitment of c-Src underlies the proliferative action of glucagon-like peptide- 1 in pancreatic $\beta$ INS832/13 cells. Molecular and Cellular Endocrinology 364 65-70. (doi:10.1016/j.mce.2012.08.010)

Tang-Christensen M, Larsen PJ, Thulesen J, Romer J \& Vrang N 2000 The proglucagon-derived peptide, glucagon-like peptide-2, is a neurotransmitter involved in the regulation of food intake. Nature Medicine 6 802-807. (doi:10.1038/77535)

Thim L \& Moody AJ 1981 The amino acid sequence of porcine glicentin. Peptides 2 (Suppl 2) 37-39. (doi:10.1016/0196-9781(81)90007-3)

Turton MD, O'Shea D, Gunn I, Beak SA, Edwards CM, Meeran K, Choi SJ, Taylor GM, Heath MM, Lambert PD et al. 1996 A role for glucagon-like peptide-1 in the central regulation of feeding. Nature 379 69-72. (doi:10. 1038/379069a0)

UKPDS 1995 U.K. prospective diabetes study 16. Overview of 6 years' therapy of type II diabetes: a progressive disease. U.K. Prospective Diabetes Study Group. Diabetes 44 1249-1258. (doi:10.2337/diabetes.44.11.1249)

Unger RH, Eisentraut AM, McCall MS, Keller S, Lanz HC \& Madison LL 1959 Glucagon antibodies and their use for immunoassay for glucagon. Proceedings of the Society for Experimental Biology and Medicine 102 621-623.

Unger RH, Eisentraut AM, McCall MS \& Madison LL 1961 Glucagon antibodies and an immunoassay for glucagon. Journal of Clinical Investigation 40 1280-1289. (doi:10.1172/JCI104357)

Unger RH, Eisentraut AM, McCall MS \& Madison LL 1962 Measurements of endogenous glucagon in plasma and the influence of blood glucose concentration upon its secretion. Journal of Clinical Investigation 41 682-689. (doi:10.1172/JCI104525)

Unger RH, Ohneda A, Valverde I, Eisentraut AM \& Exton J 1968 Characterization of the responses of circulating glucagon-like immunoreactivity to intraduodenal and intravenous administration of glucose. Journal of Clinical Investigation 47 48-65. (doi:10.1172/JCI105714)

Vahl TP, Tauchi M, Durler TS, Elfers EE, Fernandes TM, Bitner RD, Ellis KS, Woods SC, Seeley RJ, Herman JP et al. 2007 Glucagon-like peptide-1 (GLP-1) receptors expressed on nerve terminals in the portal vein mediate the effects of endogenous GLP-1 on glucose tolerance in rats. Endocrinology 148 4965-4973. (doi:10.1210/en.2006-0153)

Valverde I, Rigopoulou D, Exton J, Ohneda A, Eisentraut A \& Unger RH 1968 Demonstration and characterization of a second fraction of glucagonlike immunoreactivity in jejunal extracts. American Journal of the Medical Sciences 255 415-420. (doi:10.1097/00000441-196806000-00007)

Vilsboll T, Christensen M, Junker AE, Knop FK \& Gluud LL 2012 Effects of glucagon-like peptide-1 receptor agonists on weight loss: systematic review and meta-analyses of randomised controlled trials. Diabetes, Obesity and Metabolism 14 101-111. (doi:10.1111/j.1463-1326.2012.01579.x)

Wettergren A, Schjoldager B, Mortensen PE, Myhre J, Christiansen J \& Holst JJ 1993 Truncated GLP-1 (proglucagon 78-107-amide) inhibits gastric and pancreatic functions in man. Digestive Diseases and Sciences $\mathbf{3 8}$ 665-673. (doi:10.1007/BF01316798)

Wheeler MB, Gelling RW, McIntosh CH, Georgiou J, Brown JC \& Pederson RA 1995 Functional expression of the rat pancreatic islet glucose-dependent insulinotropic polypeptide receptor: ligand binding and intracellular signaling properties. Endocrinology 136 4629-4639. (doi:10.1210/en.136.10.4629) 
Whitaker GM, Lynn FC, McIntosh CH \& Accili EA 2012 Regulation of GIP and GLP1 receptor cell surface expression by $\mathrm{N}$-glycosylation and receptor heteromerization. PLoS ONE 7 e32675. (doi:10.1371/journal.pone.0032675)

Willms B, Werner J, Holst JJ, Orskov C, Creutzfeldt W \& Nauck MA 1996 Gastric emptying, glucose responses, and insulin secretion after a liquid test meal: effects of exogenous glucagon-like peptide-1 (GLP-1)-(7-36) amide in type 2 (noninsulin-dependent) diabetic patients. Journal of Clinical Endocrinology and Metabolism 81 327-332. (doi:10.1210/jc.81.1.327)

Wu YQ, Limburg DC, Wilkinson DE, Jackson P, Steiner JP, Hamilton GS \& Belyakov SA 2003 Neuroprotective effects of inhibitors of dipeptidyl peptidase-iV in vitro and in vivo. Advances in Experimental Medicine and Biology 524 351-355. (doi:10.1007/0-306-47920-6_42)

Wynne K, Park AJ, Small CJ, Patterson M, Ellis SM, Murphy KG, Wren AM, Frost GS, Meeran K, Ghatei MA et al. 2005 Subcutaneous oxyntomodulin reduces body weight in overweight and obese subjects: a double-blind, randomized, controlled trial. Diabetes 54 2390-2395. (doi:10.2337/ diabetes.54.8.2390)

Wynne K, Park AJ, Small CJ, Meeran K, Ghatei MA, Frost GS \& Bloom SR 2006 Oxyntomodulin increases energy expenditure in addition to decreasing energy intake in overweight and obese humans: a randomised controlled trial. International Journal of Obesity 30 1729-1736. (doi:10.1038/ sj.ijo.0803344)

Wynne K, Field BC \& Bloom SR 2010 The mechanism of action for oxyntomodulin in the regulation of obesity. Current Opinion in Investigational Drugs 11 1151-1157.

Zhu L, Tamvakopoulos C, Xie D, Dragovic J, Shen X, Fenyk-Melody JE, Schmidt K, Bagchi A, Griffin PR, Thornberry NA et al. 2003 The role of dipeptidyl peptidase IV in the cleavage of glucagon family peptides: in vivo metabolism of pituitary adenylate cyclase activating polypeptide-(1-38). Journal of Biological Chemistry 278 22418-22423. (doi:10.1074/jbc. M212355200)

Received in final form 23 September 2012

Accepted 27 September 2012

Made available online as an Accepted Preprint 27 September 2012 